\title{
Contribution of Explosive Power Muscle Arms and Concentration of Floating Service in Volleyball
}

\author{
Erianti*, Yuni Astuti, Zulbahri \\ Department of Physical Education \\ Faculty of Sport Science \\ State University of Padang \\ Padang, Indonesia \\ erianti@fik.unp.ac.id \\ yuniastuti@fik.unp.ac.id \\ zulbahri@fik.unp.ac.id
}

\begin{abstract}
This study aims to determine the contribution of the arm muscle explosive power and concentration on service capabilities on volleyball Student Sports Education. This type of research is correlational. The population in this study are students of the Department of Physical Education who take advanced courses totaling volleyball as many as 37 people. A purposive sampling technique took the sample, so the sample size is $\mathbf{2 6}$ students' son. The collection of data for the variable arm muscle explosive power using the Medicine ball put and concentration using a questionnaire concentration grid exercise. While services such as servicing ability tests. Data were analyzed using product-moment correlation and correlation followed with a double. The results showed that: (1) the explosive power of the arm muscles have a significant relationship with the service capabilities on volleyball, (2) the concentration does not have a significant relationship with the service capabilities on volleyball, (3) the explosive arm muscles and concentration jointly have a significant relationship with the service capabilities on volleyball and accepted as valid by empirical.
\end{abstract}

Keywords-Explosive power, arm Muscle, concentration, floating service

\section{INTRODUCTION}

The availability of "quality human resources who have excellent physical, mental and social conditions and mastery of science and technology are indicators of the success of a nation's development" [1].Education Department sports is one of the departments that exist in the environment of the Faculty of Sport Science has the vision, mission and objectives listed in (profile majoring in physical education) which is as follows: the vision of study program penjaskesrek "Creation of personnel Personnel Physical, Sports and Health quality, superior intellectually and morally, to master science and technology that is based on IMTAQ and is responsible for developing Physical Education, Sport and Health in the interests of the global community"[2]. While the mission penjaskesrek study program are: a) holding the Academic and Professional
Education in the field of Physical Education and Health, b) creating a graduation owned Enterprenurship insights in the field of Physical Education and Health,

Whilethe purpose is: 1 menghasilkan graduate physical education personnel, sports and health which have competence in the field of secondary and basic education

2) produce interpreneurship personnel such as: physical fitness instructor and qualified massage, 3) produce graduates who can access and create jobs in the field of physical education, sports and health in accordance with the needs of society both nationally and internationally, 4) menghasilkan graduates capable of conducting research in the field of physical education, sports and health, 5) menghasilkan graduates capable of performing community service in the field of physical education, sports and health, 6) make it easier for graduates to get jobs that are relevant.

In order to realize the vision and mission of the above, it is compulsory for students to attend various courses knowledge and skills and other educational sciences. Among the sports skills courses advanced options that should be followed by students of the Department of Physical Education Penjaskesrek namely volleyball advanced courses and weighs 3 credits.

Synopsis volleyball advanced courses include among others' understanding of ideas, history, organization, techniques and regulations as well as the skills to play volleyball with the coordination of the basic movement and was able to make the exercise pattern of the advanced volleyball lecture "(FIK UNP). Thus it can be interpreted later after completing the course students advanced volleyball are expected to have knowledge and mastering the techniques, rules of the game, volleyball advanced skills and the ability to teach others.Based on observations by the author in the field againstStudents take courses in advanced volleyball is still a lot To do error while serving on, So that the ball hit often caught in the net, wide in the side or out of the field in the extension linethe back of the field. In addition to the punches that do to the ball not hard and not over the net. 
One technique that must be mastered by students is on engineering services. A student can master the skills and able to serve well on a lot of factors that influence it. To get the top service achievement ability is good and true course many supporting factors that influence it. To achieve the glorious achievement is determined by the supporting factors that work together, among others, physical condition, tactics, techniques and mental ". In the game of volleyball is likely to occur over five sets and took more than sixty minutes, then in this case for an athlete must need aerobic endurance $\left(\mathrm{VO}_{2} \max \right)$ Good " [2].So also in generating a serve over hard would require explosive power of the arm muscles, eye-hand coordination and abdominal muscle strength and flexibility.

As well as servicing on the volleyball, the mastery of technique on good service and really give a meaningful role to the results of the service performed, as well as mental condition which in the mental concentration are not experiencing stage fright when servicing over. The physical condition of the arm muscle explosive power and concentration is a component of physical and mental conditions that are important in all sports activities included in serving on the volleyball game. This is confirmed by the data of students who take courses in advanced level volleyball half of January to June 2019 by the author of Fresh Water volleyball field. Most of the students do not yet have the ability to serve up good and proper from experiments in which students are only able to serve up targeted 8 times out of 10 occasions and even then student athletes the rest short of expectations there are 4 and 5 times the target. This condition raises concerns among a team of lecturers and students themselves, because the ability to serve on one of the advanced capabilities to play volleyball to be owned or controlled by each student.

Failure students get good grades in college volleyball certainly raises the question advanced by both the students and the teaching team. From the lecturer said that everything has been given or taught to students, while in terms of students suggested that they find it quite difficult to serve on, especially for female students. Most of them do not understand the factors that determine their success in serving on. Although many factors that determine the ability of a service on, but the explosive power factor bicep and concentration considered more decisive level of ability in servicing over. So on this occasion the author wants to conduct a study with the title:

Volleyball sports games is a big ball game with a fast tempo movement, so the time to play the ball very limited and if you do not master the technique properly and correctly will allow the occurrence of errors greater technique. One technique in the game of volleyball that is servicing techniques.Servis is the beginning of the game or can be regarded as the opening blows to start a game ". Service is the only technique that is used to start a game ". The same thing was also described by PBVSI "services is an attempt to enter the ball into play by a player who is in the right rear area of the service". [3] [4]

Explosive power is one component biomotorik important in sports, because the explosive power will determine how hard to hit, how high one can jump, how fast it can run and so on. Explosive power arm muscle is one of the basic abilities of physical condition which is the main focus in the achievement of volleyball, particularly in servicing over. Point by point can be achieved if a service attacks on more piercing to the opponent, causing difficulty in anticipating the ball. Explosive power is the product of two capabilities that power (strength) and velocity (speed) to do the maximum force in a very quick time. "Explosive power is the ability to cope with the load / barriers with a high speed of muscle contraction" [3]. "Concentration is the ability to focus on tasks with uninterrupted and unaffected by stimuli that are internal and external" [6]. Concentration as constant change associated with the two dimensions of wide (width) and dimension of concentration (focus).

\section{METHOD}

This study belongs to the type of correlational research, followed by calculating the contribution of independent variables (predictors) arm muscle explosive power and concentration on the dependent variable (criterion) servicing capabilities on volleyball student of Physical EducationFaculty of Sport Science, State University of Padang, The research was conducted at the Department of Physical Education Faculty of Sport Sciences (FIK) UNP, volleyball court Freshwater, the students who take courses in advanced volleyball. The sample in this study were as many as 26 students son. This study analyzes the techniques used are: Pearson Product Moment Correlation technique

\section{RESULTS AND DISCUSSION}

\section{Result}

\section{Explosive power Leg Muscles}

Data arm muscle explosive power of 26 students of Department of Physical Education Faculty of Sport Science UNP, obtained the highest score of 10.48 and the lowest score of 7.03, range (distance measurement) 3.45. The distribution of scores generate the arithmetic mean (mean) of 8.94, the mean (median) 17.51 and the standard deviation (standard deviation) of 0.85 . The frequency distribution of explosive power data results bicep see table 1 .

Table 1.

Results The frequency distribution data Explosive Muscle Power Sleeve Student Department of Physical Education

\begin{tabular}{|c|c|c|}
\hline class interval & $\begin{array}{c}\text { absolute } \\
\text { frequency }\end{array}$ & $\begin{array}{c}\text { The relative } \\
\text { frequency }\end{array}$ \\
\hline 7.03 to 7.72 & 2 & 7.69 \\
\hline 7.73 to 8.42 & 4 & 15.38 \\
\hline
\end{tabular}




\begin{tabular}{|c|c|c|}
\hline 8.43 to 9.12 & 9 & 34.62 \\
\hline 9.13 to 9.82 & 8 & 30.77 \\
\hline 9.83 to 10.52 & 3 & 11.54 \\
\hline amount & 26 & 100 \\
\hline
\end{tabular}

From the results of the data that has been stated above, it can be concluded that as many as 13 people (50\%) had muscle explosive power arm with a score above the average group score, and no one is sure who score in the group average. As for the below average group score be as many as 13 people (50\%).

\section{Concentration}

Data variable concentrations of 26 students of Department of Physical Education Faculty of Sport Science, State University of Padang, obtained the highest score of 20.20 and the lowest score of 6.06 , while the range (distance measurement) 14.14. Furthermore, the distribution of scores generate the arithmetic mean value (mean) of 13.29 and a middle value (median) 13.13, as well as the standard deviation (standard deviation) of 3.18. The frequency distribution of data concentration results student of Physical Education Faculty of Sport Science, State University of Padang can be seen in table 2.

Table 2.

Frequency Distribution Data Results Concentrations Students

Department of Physical Education

\begin{tabular}{|c|c|c|}
\hline class interval & $\begin{array}{c}\text { absolute } \\
\text { frequency }\end{array}$ & $\begin{array}{c}\text { The relative } \\
\text { frequency }\end{array}$ \\
\hline 6.06 to 8.88 & 2 & 7.69 \\
\hline 8.89 to 11.71 & 5 & 19.23 \\
\hline 11.72 to 14.54 & 12 & 46.15 \\
\hline 14.55 to 17.37 & 5 & 19.23 \\
\hline 17.38 to 20.20 & 2 & 7.69 \\
\hline amount & 26 & 100 \\
\hline
\end{tabular}

Referring to Table 2 above, it can be concluded that out of 26 students of Department of Physical Education Faculty of Sport Science, State University of Padang for variable concentrations, which have a class interval 6.06 to 8.88 , there were $2(7.69 \%)$, grade interval 8.89 to 11.71 is 5 people $(19.23 \%)$ and grade interval of 11.72 to 14.54 is 12 people (46.15\%). Then who has the class interval from 14.55 to 17.37 is 5 people (19.23\%) and who have grade interval of 17.38 to 20.20 that there are two people $(7.69 \%)$. Based on the results of the data that has been stated above, it can be concluded that out of 26 students from the Department of Physical Education Nikken UNP, which has a concentration with a score above average group is about 13 people $(50 \%)$ and score in the group average is not No one is likely to have it.

\section{Serviceability Top volleyball}

Data service capabilities on volleyball of 26 students of Department of Physical Education Faculty of Sport Science, State University of Padang, obtained the highest score was 41 and the lowest score 16 . While the range (distance measurement) is 25. Furthermore, the distribution of scores generate the arithmetic mean value (mean) 29.35 and a middle value (median) 28.5. While the standard deviation (standard deviation) was 6.72 . The frequency distribution data results service capabilities on volleyball student of Physical Education Faculty of Sport Science, State University of Padang can be seen in Table 3.

Table 3.

Distribution of Data Results Top Serviceability volleyballCollege student

Department of Physical Education

\begin{tabular}{|c|c|c|}
\hline class interval & $\begin{array}{c}\text { frequency } \\
\text { Absolut }\end{array}$ & $\begin{array}{c}\text { Relative } \\
\text { frequency }\end{array}$ \\
\hline $16-21$ & 3 & 11.54 \\
\hline $22-27$ & 7 & 26.92 \\
\hline $28-33$ & 9 & 34.61 \\
\hline $34-39$ & 5 & 19.23 \\
\hline$\geq 40$ & 2 & 7.69 \\
\hline Amount & 26 & 100 \\
\hline
\end{tabular}

Based on Table 3 above, it can be concluded that out of 26 students of Department of Physical Education Faculty of Sport Science, State University of Padang, which has a class interval $16-21$ is $3(11.54 \%)$, for the class interval 22-27 is as much $7(26.92 \%)$ and the class interval 28-33 that as many as 9 people $(34.61 \%)$. While having a class interval $34-39$ is 5 people (19.23\%) and $\geq$ 40 for grade interval of only $2(7.69 \%)$. Based on the results of data on variable servicing ability on volleyball student of Physical Education Faculty of Sport Science, State University of Padang, which has been stated above, it can be concluded that that have the ability to serve up volleyball with scores above average group numbering as many as 13 people (50\%) and those in the score in the average group score is only one person (3.85\%). As for the below average group score be as many as 12 people $(46.15 \%)$. Based on the test results in the observation Lilliefors Lo $<\operatorname{Lt} \alpha=0.05$ ) If Lobservasi smaller than Ltabel this means that the three data variables studied were the explosive power arm muscles, concentration and the ability to serve up volleyball is a normal distribution.

The results of correlation analysis between the explosive power of the arm muscles (X1) with the ability to serve up volleyball (Y) students of the Department of Physical Education Faculty of Sport Science, State University of Padang is obtained rhitung 0,425> rtabel 0,388 , meaning that there is a significant correlation (means) between the explosive power arm muscles with the ability to serve up volleyball student of Physical 
Education Faculty of Sport Science, State University of Padang.To test the correlation coefficient significant muscle explosive power arm with the ability to serve up volleyball $t$ test. Results of tests of significance was found $t=2.30>t$ table 1.71. It can be concluded that there is a significant relationship (significant) between the arm muscle explosive power with the ability to serve up volleyball student of Physical Education Faculty of Sport Science, State University of Padang,accepted as true by empirical.

Furthermore, to determine the contribution of the arm muscle explosive power servicing ability on volleyball student of Physical Education Faculty of Sport Science, State University of Padangdeterminant of formula $\mathrm{r} 2=0.4252 \times 100 \% \times 100 \%=18.06 \%$. This means that the arm muscle explosive power contribution to the ability of a service on volleyball student of Physical Education Faculty of Sport Science, State University of Padang amounted to $18.06 \%$. While the remainder caused by other variables.

The results of the analysis of the correlation between the concentration (X2) with the ability to serve up volleyball (Y) obtained rhitung 0.143 < rtabel 0,388, meaning that the second hypothesis was rejected or not there is a significant correlation (means) between the concentration with the ability to serve up volleyballstudents of Department of Physical Education Faculty of Sport Science, State University of Padang, Based on the results obtained multiple correlation calculation rhitung $=0,462>$ rtabel $=0.388$. To see the significance of this relationship between the double correlation, conducted by $\mathrm{F}$ test Fhitung price sought is 3.62, while Ftabel is 3.42. Turns Fhitung> Ftabel or $3.62>3.42$ at $£ 0.05$. Thus there is a significant correlation (means) between the explosive power of the arm muscles (X1) and the concentration (X2) together with the ability to serve up volleyball (Y) students of the Department of Physical Education Faculty of Sport Science, State University of Padang. Furthermore, to determine the contribution of muscle explosive power arm (X1) and the concentration (X2) jointly towards servicing ability on volleyballstudents of Department of Physical Education Faculty of Sport Science, State University of Padang determinant formula $\mathrm{r} 2=0.4622 \mathrm{x}$ $100 \% \times 100 \%=21.34 \%$. This means that the contribution arm muscle explosive power (X1) and arm muscle explosive power (X2) jointly towards servicing ability on volleyball student of Physical Education Faculty of Sport Science, State University of Padang amounted to $21.34 \%$, the rest is influenced by other variables.

\section{DISCUSSION}

1. Explosive power relations arm muscles on volleyball servicing Capabilities Student Sports Education
The first finding in this study stating that there is a meaningful relationship (significant) of0,425 Among the arm muscle explosive power with the ability to serve up volleyball student of Physical Education Faculty of Sport Science, State University of Padang, and contributed $18.06 \%$, This means that the better the student arm muscle explosive power, the better the service capabilities on volleyball. Based on the results of the research that has been described above, it is accepted as true by empirical that explosive power arm muscles contribute and have a meaningful relationship with the service capabilities on volleyballcollege student. Services on the volleyball game is a technique or how to hit a ball that bounced ownThe upper front higher than the head, hands immediately hit the ball back from the ball and the force of the ball must run to cut the center line of the ball. The implementation of service on do in the area behind the lines and did not exceed the extension line of the side lines or in accordance with applicable regulations. The ability of service above must be owned by the students, because some sources are studied said that in accordance with the progress of the development of volleyball serve not only as a punch opening or early blow to start a game, but already the initial attack off the ball region opponent to earn points / numbers. This means that the ball must be hit with a sharp hard and leads to the opponent's game field, to be able to do this one factor is supported by the ability of the explosive power of the arm muscles.

Ability arm muscle explosive power has been proven in this study have a relationship and contribute to the servicing capability on students of Department of Physical Education. Explosive power can be a product of two capabilities that power (strength) and velocity (speed) to do the maximum force in a very quick time. Explosive power is the ability to cope with the load / barriers with a high speed of muscle contraction ". So obviously the higher the ability of the explosive power of the arm muscles, the better the ability of the service on the student performed. It is not easy for a person to have the explosive power with a good arm muscles, because the ability of the explosive power can be influenced by several factors, including the type of muscle fibers, extensive skeletal muscle, the number of cross bridges, energy metabolism system,

\section{Relations Concentration Capabilities volleyball serve on Student Sports Education}

The second discovery in this studystating that there is no significant relationship (significant) between the concentration with the ability to serve up volleyball student of Physical Education Faculty of Sport Science, State University of Padang. This means that the better the level of concentration of the person, then it could mean that the better the service capabilities on volleyball. Supposedly the higher concentration of 
students, the better the ability to serve up. In accordance with the findings of research that has been stated above, it is clear that the concentration of students in serving on not having any significance. This is certainly very interesting because in Indonesian Dictionary "is focusing concentration, mind, and soul and a physical object" [7]. In this case of course, supposed to be the ability of concentration of attention, mind, and soul and physically students needed or required when servicing the top so that the implementation is done by the service on a serious, more focused, and the ball can be hit and directed to the desired target. Keep in mind that many factors affect the concentration, kususnya concentration in learning. Among the environment such as noise, lighting, tenpratur and design study. Then learning modalities, as more information is received and absorbed by the students, especially about technique or how to perform service on, the capability must be getting better concentration and focus to serve on. and the lives and physical integrity of students required or needed when serving on so that the implementation of service on the taken seriously, more focused, and the ball can be hit and directed to the desired target. Keep in mind that many factors affect the concentration, kususnya concentration in learning. Among the environment such as noise, lighting, tenpratur and design study. Then learning modalities, as more information is received and absorbed by the students, especially about technique or how to perform service on, the capability must be getting better concentration and focus to serve on. and the lives and physical integrity of students required or needed when serving on so that the implementation of service on the taken seriously, more focused, and the ball can be hit and directed to the desired target. Keep in mind that many factors affect the concentration, kususnya concentration in learning. Among the environment such as noise, lighting, tenpratur and design study. Then learning modalities, as more information is received and absorbed by the students, especially about technique or how to perform service on, the capability must be getting better concentration and focus to serve on. Keep in mind that many factors affect the concentration, kususnya concentration in learning. Among the environment such as noise, lighting, tenpratur and design study. Then learning modalities, as more information is received and absorbed by the students, especially about technique or how to perform service on, the capability must be getting better concentration and focus to serve on. Keep in mind that many factors affect the concentration, kususnya concentration in learning. Among the environment such as noise, lighting, tenpratur and design study. Then learning modalities, as more information is received and absorbed by the students, especially about technique or how to perform service on, the capability must be getting better concentration and focus to serve on.
Behavioral and social factors can affect concentration, just misalnyanya technologies such as the internet, television can affect a person's behavior and attitude. Furthermore fisikologi factors can also affect how the attitudes and behavior of students in learning, such as students having problems with ligkungan around, families, this will affect the student pisikologi in concentrate. Although in this study there was no significant correlation with the ability to serve on the student, but it is also necessary for students to increase the concentration in each study, such as learning to improve service techniques above.

3. Explosive Power Oto relationship Limbs And Concentration Together With service capability on volleyball

findings Thirdin this study stated that there is a significant relationship (significant) arm muscle explosive power and concentration together with the ability to serve up volleyball student of Physical Education Faculty of Sport Science, State University of Padang, as well as contributing amounting to $21.34 \%$, That is jointly arm muscle explosive power and concentration have sinifikan relationship and accepted as true by empirical with the ability to serve up volleyball. From the above findings it is clear that the higher the explosive power arm muscles and concentration possessed by students, the better the ability of the service on his accomplishments. When we see the results of data from some students about the ability of the explosive power of the arm muscles scores above average group and a concentration below the group average but the ability SEVIS it is high, such as Reski Yonetra Son. There are also students who are high topped servicing capabilities while explosive muscular arm below the group average and the concentration is not too high.

\section{CONCLUSION}

Based on the results of data analysis and discussion, it can be concluded that: 1) Explosive power arm muscles have a significant relationship with the service capabilities on volleyball and received kebenaranya empirically, and contributed $18.06 \% .2$ ) The concentration does not have a significant relationship with the service capabilities on volleyball and accepted as true by empirical, 3) Explosive power arm muscles and concentration jointly have a significant relationship with the service capabilities on volleyball and accepted as true by empirical, and contribute amounting to 21.3

\section{REFERENCES}

[1] Z. Zulbahri, "Tingkat Kemampuan Daya Tahan Jantung dan Pernafasan Mahasiswa Pendidikan Olahraga dan Kesehatan Universitas Pasir Pengaraian", Gelanggang Olahraga: Jurnal Pendidikan Jasmani dan Olahraga, vol. 3, no. 1, pp. 96-101, Oct. 2019. 
[2] Syafruddin. "Sports Coaching Science". Padang: Nikken UNP, 2004, pp. 76.

[3] Erianti. "Textbook volleyball". Padang: Faculty of Sport Science. Padang State University, 2011, pp. 28.

[4] M. N. A. Setiawan. "Increasing Aerobic Durability Skill by Practicing Extensive Interval Method for Volleyball Athlete in Rokan Hulu Regency", Applied Science and Technology, vol. 2, no. 1, pp. 129-131, Feb. 2018

[5] Arsil. "Development of Physical Condition". Padang. Nikken UNP. 2008 , pp. 36

[6] Komarudin. "Sports Psikolgi". Bandung: PT Young Rosdakarya offset. 2013, pp. 78.

[7] Bachtiar. "Knowledge Basics volleyball game". Padang: Nikken UNP, 1999, pp. 16. 